\title{
Power of Arbitration Agreement
}

\author{
Raqiya Abdul Jabbar Ali ${ }^{1} \&$ Majd Almanasrah ${ }^{1}$ \\ ${ }^{1}$ Faculty of Law, Middle East University, Amman, Jordan \\ Correspondence: Raqiya Abdul Jabbar Ali, Faculty of Law, Middle East University, P.O. Box 383, Amman \\ 11831, Jordan. E-mail: drraqiya2000@gmail.com
}

Received: March 3, 2019

doi:10.5539/jpl.v12n2p71

\author{
Accepted: March 27, 2019 Online Published: May 30, 2019 \\ URL: https://doi.org/10.5539/jpl.v12n2p71
}

\begin{abstract}
Arbitration certainly plays a pivotal role in characterizing commercial relations that are of various kinds among individuals, and this, in turn, leads to make arbitration clause contained within contracts so as to settle disputes created by such contracts. It, in a way or another, aims at preventing litigants from recourse to a court of law. Instead, litigants should be fully committed to refer their disputes to a well-trusted arbitrator whose responsibility is to adjust their de facto or potential dispute, and should also be committed to put the arbitrator's judgment into effect. This paper sheds some light on determining the principle of power of arbitration agreement when an original contract is prepared. It provides the definition, the concept and the legal foundation of power of arbitration agreement.
\end{abstract}

Keywords: arbitration agreement, arbitration clause, the original contract, contractual parties

\section{Introduction}

Arbitration is basically viewed as being a means of arbitrating those disputes arisen among certain parties. It had been familiar from antiquity when old communities actively adopted it to put an end to their members' disputes. Nowadays, it has become fully recognized by internationally and nationally legislative regulations. In other words, arbitration certainly plays a pivotal role in characterizing commercial relations that are of various kinds among individuals, and this, in turn, leads to make arbitration clause contained within contracts so as to settle disputes created by such contracts.

In addition, arbitration, in a way or another, aims at preventing litigants from recourse to a court of law. Instead, litigants should be fully committed to refer their disputes to a well-trusted arbitrator whose responsibility is to adjust their de facto or potential dispute, and should also be committed to put the arbitrator's judgment into effect. However, some of jurists describe arbitration as being one of law problems.

That arbitration is reckoned as a way of adjusting a dispute as well as a way of considering any contractual provisions entails that arbitration clause has to be necessarily valid and of a considerable influence even though the original contract is annulled. The reason behind such a procedure is that an arbitrator's authority must always be available throughout the act of arbitration regardless of any attempt on one of litigants' part to contest the original contract.

This paper sheds some light on determining the principle of power of arbitration agreement when an original contract is prepared. It provides the definition, the concept and the legal foundation of power of arbitration agreement.

\section{The Study Design}

The present paper is mainly divided into three major sections. The preliminary section is concerned with the concept of arbitration agreement. The second one is devoted to account for the term of power of arbitration agreement. The third section deals with the legal foundation of power of arbitration agreement.

The preliminary section is also subdivided into two subsections. Generally, the first is to explore arbitration clause. It is also categorized into two minor subsections. In the first place, the definition and significance of power of arbitration agreement are tackled, while the next one covers three topics: the theory of circumstantial effects of contract annulment, the theory of separation between arbitration agreement and the original contract, and the theory of jurisdiction of arbitration. The second subsection of the preliminary one is concerned with the stipulation of arbitration. The paper concludes with a set of results and recommendations. 


\section{Preliminary Section: The Concept of Arbitration Agreement}

Recourse to the international commercial arbitration is usually resulted from yielding to an agreement reached by different parties in relation to the contracts of international trade. These parties agree to go to arbitration instead of going to a court of law. The arbitral agreement may either take a form of an independent contract, or may be one of the provisions of the original contract (Al-Hassan, 2010). Nevertheless, the arbitral agreement can discussed via two versions: the former deals with the concept of arbitration clause, while the latter is concerned with the stipulation of arbitration.

\subsection{Arbitration Clause}

Two conflicting parties may agree to accept arbitration on condition that a provision mentioned in a contract states that they agree, in the case of a dispute, to consult a certain arbitrator or arbitrators, and this two-conflicting parties agreement is usually called arbitration clause (Hayawi, 2007).

In other words, arbitration clause is an agreement reached by different contractual parties on adjusting such and such a forthcoming dispute due to arbitration. In this regard, It serves the purposes of settling a potential dispute or it is generally put into effect regardless of whether there is primarily a dispute resulted from the provisions of the original contract. Arbitration clause may either be stated in the same original contract or may be mentioned in the coming agreement before having any disputes.

Some jurists have defined arbitration clause as an agreement according to which two parties have to be committed to adopt it without recourse to a court of law. Arbitration clause is often subsumed under the provisions of the original contract in order to put an end to parties' future disputes when that contract comes into effect or interpreted (Niseif, 2001). It is not necessary for arbitration clause to be included in the original text of a contract, but it may also be written in a separate paper sheet. This, in turn, does not distort its natural aspect as being arbitration clause simply because it has generally been accepted before having any potential dispute. Arbitration clause can easily be drafted in any language accepted by all of parties. It does not matter what type of the language is as long as it would finally be interpreted to express parties' desire to go to arbitration. However, it is usual to write arbitration clause using the same language as that of the original contract. Importantly enough, arbitration clause is also accounted for as being an agreement shown in any contract whereby forthcoming disputes are to be arbitrated, and above all it must be treated either as one of the contractual provisions or as an independent agreement (Al-Masri, 2000).

On a national ground, Iraqi Procedures Law numbered (83) and issued in 1969 stipulates in item (252): "An agreement is not put down unless it is codified". As far as French Procedures Law issued in 1991(item 144) is concerned, arbitration clause is described as an agreement according to which two parties undertake (via a contract) to accept arbitration whenever they are involved in disputes with each other (Barbari, 2007). Thus, a potential dispute may have a precondition through which arbitration necessitates settling disputes without recourse to a court of law. In short, it is looked upon as an agreement among parties to exclude the role played by a court of law to adjust potential disputes (Al-Masri, 2000).

As for Egyptian Law, Arbitral Law numbered (27) and issued in 1991 (item 12) was very much elaborated. It stipulates "arbitration precondition must be written. Otherwise, it becomes untrue. It will be considered written if it includes a deed signed by two parties or if it contains the two parties' letters, telegraphs or any other written means of communication" (Barbari, 2007).

\subsection{Stipulation of Arbitration}

Stipulation of arbitration (or arbitration document) refers to an agreement reached by two parties in a case that they have been involved in a dispute, and their dispute must be subjected to arbitration. Stipulation of arbitration has been legitimated by item (10) of Egyptian Arbitritation which states that arbitration agreement is an agreement according to which two parties are arbitrated in an attempt to settle most, if not all, of de facto or potential disputes caused by a particular legally contractual or non-contractual relation. Moreover, stipulation of arbitration can possibly be valid if the dispute in question is a matter of a lawsuit brought to a court of law.

When having been authorized, stipulation of arbitration can easily be preceded or followed by arbitration clause, and thus its authorization has not totally led to nullify prior arbitration clause unless parties agree to do so. What characterizes stipulation of arbitration is that it comes into being immediately after the so-called dispute arises. However, when stipulation of arbitration has been made before the dispute arises, it becomes untrue, and this, by itself, is something very necessary to validate it.

That a dispute arises refers to two main things: two parties really get into a dispute or the dispute is still being existent. The following are the basic issues stipulation of arbitration should include: 
1) Specifying the cause of a dispute brought to arbitration.

2) Determining the parties involving in a dispute and their addresses if possible.

In Iraq, arbitration clause is often taken for granted simply because most of the contracts are prepared in advance like insurance contracts and entrepreneurial contracts must have such clause (Hayawi, 2007). On the other hand, stipulation of arbitration, in both Egypt and France, has mostly been made when parties refer their dispute to a court of law, and it is possible for them to agree that the dispute is being discontinued as soon as circumstances are fit for having stipulation of arbitration.

3) Parties' freedom of selecting arbitrators.

One of the most important questions in dealing with stipulation of arbitration is that parties are not restricted to select arbitrators. International European Agreement in item (4) affirms that parties are completely free to choose arbitrators whose task is to resolve an existent dispute.

Once being chosen, arbitrators would be known as specialists. On other hand, in some cases, parties may not determine those who are tasked for arbitration and thus other authorities will undertake such a mission. European Agreement has set chamber of commerce (of the country which the two parties have chosen) the task of arbitration as well as the place of arbitration. In other words, this agreement, via organizational texts, deals with the question or the matter of specifying a court of law which is responsible for considering a dispute.

\section{The Concept of Power of Arbitration Agreement}

\subsection{Definition of Power of Arbitration Agreement}

What is meant by power of arbitration is that adopting arbitration remains valid and effective even though an agreement is regarded as being false or untrue (Sami, 2010). Sometimes, arbitration clause can be looked upon as an independent contract with its own sufficient characteristics: it is not chiefly based on the original contract (Shata, 2009).

Item (3) of Iraqi International Commercial Law of Arbitration defines power of arbitration agreement as a case in which arbitration clause is considered an independent agreement isolated from other contractual provisions, and above all any attempt to nullify the contract (within which it is contained) does not highly affect it (Al-Ahadab, 2008).

What is worth-noting here is that this definition harmonizes very well with what jurisprudence has stated in relation to the definition of power of arbitration agreement. However, it has been elaborated to some extent and it suffices to state as follows: it is a case in which arbitration clause is completely independent of the original contract. It has also been supposed to mention this definition in item (1) when referring to legal terms.

Egyptian Legislation is viewed as one of the important legislations that has adopted power of arbitration agreement instead of the original contract in which it is formerly included. Before Egyptian Arbitral Law was issued in 1994, a heated juristic debate had been opened on how arbitration clause is independent of the original contract. It is argued that power of arbitration agreement should explicitly be isolated from the original contract. Some of jurists believe that arbitration clause must not be independent of the contract. For this reason, when somebody alleges that the contract is untrue, arbitration authority cannot consider such an allegiance and thus it is obliged to halt the procedures in question as soon as a judgment is pronounced to settle the annulment of the contract (Sami, 2010).

Some jurists are of the opinion that it is the contract of arbitration with which an arbitrator inevitably becomes in a leading authority. If the contract is the subject of fierce debate among parties, then this debate will surely affect arbitration clause and this also shows that the latter is subsidiary to the former. Other jurists think that arbitration clause does not have a considerable effect on the original contract even though it is mentioned throughout the contractual provisions (Al-Hassan, 2010).

The following crucial results are brought about as to how to apply power of arbitration agreement to a contract (Al-Jammal, 1998):

1) Whether or not the contract is annulled due to a particular reason such as having an incompetent party does not affect the related arbitration clause: it remains true and highly effective. That one of the parties is incompetent would definitely distort the original contract as well as arbitration clause simply because both of them must be authorized via a full competence and an obligatory power. Moreover, a contractual annulment or determination does not stand as a stumbling rock in front of arbitration clause so that deciding on the validation or invalidation of the original contract is out of the authority of a court of law. 
2) That arbitration clause comes to an end by means of its self-annulment does not have any effect on the original contract to be fruitful and dominant. In such a case, judicature has the authority to settle disputes via a set of general rules.

3) Arbitration authority has a full right to consider those issues closely related to its own field.

Central to other Arabic legislations that have adopted power of arbitration agreement is the Bahraini Arbitration Law numbered (9) and issued in 1994. Its item (16) states that it is permissible for arbitration authority, according to its own concerns, to consider any demurrers related to arbitration agreement and its validation. Accordingly, arbitration clause is looked upon as pivotal part of a contract as if it is something independent of other contractual provisions. When arbitration authority issues a decree stating the annulment of contract, arbitration clause, in turn, would not be annulled at all (Al-Ahadab, 2008).

\subsection{Significance of Power of Arbitration Agreement}

When arbitration clause is to be independent of the original contract in which it is included is so significant in that there is a growing tendency to save time and to reduce procedures. However, when arbitration clause is mentioned in the original contract, it is automatically independent by itself, and this, in turn, provides some sort of possibility to verify the validation or invalidation of the original contract by means of arbitrators (Salama, 2004).

It is worth-stating here is that having de facto or potential arbitration closely related to the original contract leads that it would be so hard for arbitral procedures to put into effect unless the national court of law settles disputes. In other words, the relation drawn between arbitration clause and the original contract does not make an arbitrator be empowered to arbitration whenever one of the contractual parties invalidates the contract itself (Sami, 2010). The arbitrator should simultaneously consider both the validation of the original contract and arbitration clause.

In a case that the original contract is contested, arbitration would be under the control of a court of law, and the arbitral procedures would not be put into effect unless the court of law verifies the validation of the original contract (Shafeeq, 1997).

It is not acceptable that arbitration authority will not consider a lawsuit if the original contract is annulled, and it is not also acceptable that the lawsuit would be referred to the national court of law to consider whether the original contract and arbitration clause are valid or not. If a court of law states that the contract and arbitration clause are valid, then arbitration authority can follow up its procedures. Otherwise, arbitration authority would be baseless. For this reason, power of arbitration agreement should be adopted when a contract is signed and this would not accordingly make arbitration clause closely linked to the original contract so that arbitration remains compulsory and effective.

On the other side, arbitration agreement or arbitration clause is seen as being a real contract and it has been defined by UNCIRAL in item (1/7) as "a two-sided agreement in which some contractual and non-contractual disputes must finally be settled" (Al-Hadad, 2010). Others define arbitration agreement as an agreement according to which parties are committed to settle their de facto or potential dispute via arbitration.

When involving into a financial dispute, the two parties must dissolve it by virtue of arbitration rather than by means of a court of law as required by the preconditions of arbitration agreement in question. Furthermore, this arbitration agreement is to be possible and obligatory for the two parties as shown in Egyptian and Jordanian Laws (Shata, 2009).

It is worth noting that arbitration agreement must be written in accordance with the following criteria:

1) Arbitration agreement must be codified. Otherwise, it becomes untrue. It is written when including a document signed by two parties or when including shared communicative means of two parties which, in turn, represents an agreement document.

2) Any contractual case subsumed under the rules of a model contract or an international agreement can be viewed as being a written arbitration agreement if the referral assumes that this is part of the original contract.

3) If agreed upon arbitration at the time when a court of law considers the two parties' dispute, the court has to decide on referring the dispute to arbitration and this decision is looked upon as a written arbitration agreement (Salama, 2004).

The original contract is a matter of systemizing parties' rights and organizing their legal centers. The rationale behind arbitration is that parties are willing to exclude arbitration agreement from the state (governmental) judgment and to refer it to arbitration judgment. The original contract is attributed to make parties have such a 
contract and it is usually estimated via personal standards varying considerably from one individual to another one.

A special judge as he is, an arbitrator exercises technically a judicial authority similar to that of a governmental one: he settles down a dispute throughout a binding law, and it must obligatorily be put executed by those who are involved. Therefore, this characteristic provides the arbitrator with the status that should never be inferior to the governmental judge's one (Al-Hadad, 2010).

\section{The Legal Foundation of Power of Arbitration Agreement}

Power of arbitration agreement is legally founded upon three major classes: theory of extrinsic effects of the contractual annulment, theory of arbitration agreement-the original contract distinction and theory of juridical specialization of arbitration.

\subsection{Theory of Extrinsic Effects of the Contractual Annulment}

Some of jurists believe that arbitration agreement may come into existence in accordance with a contract made after involving into a dispute, and without an agreement stated in a separate document (Sami, 2010). Arbitration agreement may also come into being according to the original contract via a contractual provision. Here, we may pose a question about the foundation according to which power of arbitration agreement can be carried out, and about the possibility of how we can benefit from theory of contractual transformation or from theory of contractual depreciation. Theory of contractual transformation is seen as a means for individuals to exchange their commitments. If provisions are fulfilled, then, it will become valid. Otherwise, it becomes untrue (Hussein, 2005)

Based chiefly on such invalidation, the contract would be null and has no any effects. However, there may be some extrinsic effects in cases when a legislator endeavors to investigate what side effects can be left as a result of invalidation. The evidence is that the contract may totally be null, but it is said to have some independent elements by which a new contract can be made with its full effects that serve parties' purposes, and these effects are usually known as "contractual transformation".

Accordingly, it is impossible to take advantage and above all activate theory of contractual transformation in the realm of power of arbitration agreement in relation to the original contract, simply because a particular contract cannot be transformed into another one unless the forgoing legal disposal is completely invalid (Hayawi, 2007). Nevertheless, if part of the original contract is untrue and the legal disposal is divisible, then the latter cannot be transformed and entails some sort of annulment (Al-Hakeem, 2015).

What is meant by theory of contractual depreciation is that a contract is seen as valid in general even though it may be overlapped with some other issues. However, the contract may be invalid if some of these issues are not true, and it, all in all, remains true as far as those true issues are contained within it (Sami, 2010).

Theory of contractual depreciation presupposes that there must be a single contract divided into two sections: one section is valid and the other is invalid. It is possible to consider the latter a separate contract if the available contractual provisions state so.

In the light of arbitration, what has been stated so far is quite true since any legal relation sharing two parties should be represented in a form of a contract or an agreement made or reached when those parties are involved in a dispute. This can be embodied by means of arbitration clause of the original contract: it is not a mere contractual provision; rather, it is an independent agreement. Besides, when having a scrutinizing look at this matter, we can easily recognize that one document, for the first sight, seems to be in a form of one contract: its primary section is devoted to draw two parties' legal relation, while the next section represents arbitration agreement (Al-Hakeem, 2015).

\subsection{Theory Arbitration Agreement-The Original Contract Distinction}

Power of arbitration agreement is one of the unchanged principles in some of positive laws that are closely tied with the International Commercial Arbitration. This principle has been manipulated either by juridical rules or by legislative tests.

In France, for instance, the French Court of Cassation pronounced sentence in relation to GOSST in 1963. It stated that on the ground of the International Commercial Arbitration, arbitration agreement, whether being excluded from any original legal disposal or included within it, is of an entire independence. Nevertheless, some exceptional circumstances with completely legal independence may emerge to isolate arbitration agreement from being affected by any probable annulment (Sami, 2010).

The English Law attempts to define arbitration agreement as follows: parties, when getting into a certain dispute 
over contracts, go to arbitration in so far as disputes have currently arisen and will arise in the future. It also points out that arbitration clause must be codified in a form of a document having some sort of a principle related to arbitration agreement.

To put it in another way, the principle of arbitration clause independence asserts very obviously that both arbitration clause and the original contract are two divergent factors. Arbitration clause is an internal contract paralleled to the original one in a way that it is self-contained, notably autonomous and independent according to its contractual provisions, regulations and rules. It usually deals with issues and cases distinct from those of the original contract, and aims at settling down probable disputes arisen from it (Al- Hadad, 2010).

The foregoing was totally confirmed the English Arbitration Law of 1996 which states in item (7): if parties do not agree upon something different from what they have already reached, then the agreement that is intentionally part of another written or unwritten one must not be reckoned as untrue, non-existent or inactive so that it has to be a fully independent one.

It is not possible for arbitration agreement to come into existence without having accompanied with the original contract. Otherwise, the contract, in the case of arbitration agreement, is out of consideration and thus is oriented to be null. By drawing a close relationship between arbitration agreement and the original contract, we mean that the relationship should be physically rather than legally available. Arbitration agreement can be made and also validated even though the contract to which arbitration agreement is attached is null for any reason. This is usually known as the principle of power of arbitration agreement of the contract and it has been adopted by numerous Arab Laws (Al-Masari, 2010).

When agreed upon arbitration, contractual parties are prevented from going to a court of law so as to resolve their dispute which necessitates some sort of arbitration. Moreover, the parties are not allowed to retreat self-intentionally arbitration agreement because it remains completely valid (Makhluf, 2001).

Some scholars think that admitting arbitration clause is something compulsory although parties agree that this arbitration clause is doomed to the original contract. The principle of power of arbitration clause becomes one of the internationally avowed principles that is widely adopted by international treaties as well as international commercial institutes of arbitration. In fact, such a principle is concerned with other regulations of organizing legally commercial arbitration, and it is not permitted for contractual parties to fringe them, simply because arbitration agreement would be null (Hayawi, 2007).

It is worth-mentioning that we disagree with the opinion stating that power of arbitration clause must obligatorily be admitted even though parties have agreed that arbitration clause is intertwined to the original contract. Power of arbitration clause may not necessarily be confirmed when the original contract is made even out of parties' desire.

In addition, dispute settlements resulted from the contractual annulment would not, in a subordinate manner, lead to the annulment of arbitration agreement. This, in turn, means that arbitration agreement is going to be inactive though mentioned in the original contract.

Accordingly, it is something important to activate power of arbitration agreement as a whole as long as it is valid by itself. But, if it is originally invalid, then it will lack a principle of independence. The lack of the principle of independence does not only make null arbitration agreement, but it also deprives it of being an agreement (Makhluf, 2001).

\subsection{Theory of Juridical Specialization of Arbitration}

That a juridical specialist is permitted to resolve disputes based on his or her own specialized field authorizes a court of arbitration to follow up its own mission even if one of the contractual parties denies the validation of arbitration agreement for the reasons that are directly concerned with arbitration clause or stipulation of arbitration rather than with the possibility of annulling the original contract.

It is common that power of arbitration agreement of the original contract interprets cases of invalidation, but it does not account for the way in which an arbitrator can continuously accomplish his own task if the contract is null because of arbitration agreement. This is really a pivotal point whose consequences may be attributed to the arbitrator's consideration of specialization. Moreover, the same point gives the arbitrator a kind of permission to consider, if necessary, the annulment of arbitration agreement: he issues certain decrees indicating that this is not subsumed under his responsibility.

In reality, the above mentioned results are in opposite to an arbitrator's reports written for the purpose of annulling arbitration agreement. The question that is posed here is: How is it possible for somebody to be a 
contractual party and an arbitrator at the same time? In this case, arbitration agreement cannot be within an arbitrator's affairs, and it becomes invalid for him (Al-Hadad, 2010).

The question of finding another foundation according to which an arbitrator can settle disputes based on his or her field of specialization is the best way to solve the problem of a party-arbitrator duality. Arbitration agreement cannot be the real source of such a matter: the principle of an arbitrator's specialization of dispute settlements. This principle can be adopted by a particular country's law of arbitration or by any other countries' laws in a way that the judgment of arbitration is possibly presented by an arbitrator to be admitted by courts of law (Al-Hadad, 2010).

For instance, if the court of arbitration held in states such as Egypt or France decides to issue a lawsuit according to which it is not specialized to look at arbitration agreement because the latter is not valid, then this decision is made on the ground of Egyptian or French Law rather than on the ground of arbitration agreement which it states it is null.

So far, the principle of an arbitrator's specialization of dispute settlements has not entirely meant that the arbitrator is free to involve in a juridical review of his or her specialization. Rather, his or her specialization of dispute settlements is monitored by governmental jurisdiction (Salama, 2004). That the arbitrator is responsible for settling disputes based on his or her own specialization stems from the fact that arbitrators are believable and fully trusted to make fair and reliable decisions concerning community members' service.

The principle of an arbitrator's specialization of dispute settlements is of a positive influence, simply because it allows arbitrators to consider by themselves their specialization of settling down parties' disputes, and this is a matter of a broad consensus of international treaties on this issue (Al-Hadad, 2010). On the other hand, this principle is also of a negative influence: it allows arbitrators not only to resolve disputes according to their different fields of specialization, but also to prioritize it. For this reason, it is postulated by virtue of the matter of priority which is subjected to a chronological concept rather than to a stepping-stone concept (Salama, 2004).

\section{Conclusion}

In the view of the foregoing, it is possible to illustrate the following results:

1) Being part of the original contract, power of arbitration agreement is considered one of the most important principles asserted by international conventions. It is characterized as having a full independence because of being divergent considerably from the original contract.

2) When two contractual parties are in an agreement, they are not allowed to go to a court of law in order to settle their dispute, because they have already agreed to go to arbitration instead. Moreover, it is not permissible for each of them to abandon arbitration by themselves at all.

3) Arbitration clause is viewed as a legal foundation according to which it becomes fully independent of the original contract, and above all it becomes valid regardless of the annulment of the latter.

4) Power of arbitration agreement comes into existence on condition that arbitration agreement is of complete validation.

5) International conventions as well as systems of international commercial arbitration are very much interested in power of arbitration agreement since it is a means of resolving international commercial disputes.

6) The definition of power of arbitration agreement stated in Iraq seems to be very much exaggerated, more digressed and unfortunately misleading.

\section{Recommendations}

1) Enacting a particular legislation related to the international commercial arbitration taking into consideration the most important components of the model law issued by the UN Committee of International Commercial Law in 1985.

2) Editing the definition of power of arbitration agreement mentioned in item (1) of Iraqi Commercial Arbitration Draft to be as follows" it is arbitration clause that is independent of the contract in which it is included".

3) Including the definition of power of arbitration agreement in item (1) of Iraqi International Commercial Arbitration Draft.

4) Executing possibly those laws issued by International Arbitration Organizations without recourse to a court of law. 
5) Making the forthcoming-issued law have a text in which arbitrators are provided with a kind of authority to resolve disputes regardless of their different fields of specializations.

\section{Acknowledgments}

We would like to express our deepest gratitude to Dr. Majid Abdulatif Ibrahim (Associate Professor of Linguistics and Translation) for translating this research paper from Arabic into English. We have highly appreciated his powerful contribution and laborious efforts.

\section{References}

Al- Jammal, M., \& Okasha, A. (1998). Arbitration in Private International and National Relations. Lebanon: Al-Halabi for Legal Publications.

Al-Ahadab, A. (2008). Encyclopedia of Arbitration in Arab Countries. Lebanon: Al-Halabi for Legal Publications.

Al-Hadad, H. A.-S. (2010). The Handbook of a General Theory of International Commercial Arbitration. Lebanon: Al-Halabi for Legal Publications.

Al-Hakeem, A. (2015). The Handbook of A Theory of Commitment. Al-Sinhuri Library.

Al-Hassan, A. H. (2010). Arbitration in Legislation and Law: A Comparative Study. Najaf: Al-Nibras Institute Press.

Al-Masri, H. (2000). International Commercial Arbitration: A Comparative Study. Egypt: Legal Books Press.

Barbari, M. (2007). International Commercial Arbitration. Cairo: Dar Al-Nahtha Al-Arabia.

Hayawi, N. A. (2007). Principles of Arbitration. Cairo: Al-Ateek Press.

Hussein, N. A. (2005). Impacts of Contract Annulment. Unpublished Doctorial Thesis Baghdad University.

Makhluf, A. (2001). Arbitration Agreement as a Means of The settlement of International Commercial Contracts. Cairo: Dar Al-Nahtha Al-Arabia.

Niseif, H. L. (2001). Arbitration and Judgment in Iraqi Law. Baghdad: Zaki Librari.

Salama, A. A. (2004). Law of International and National Arbitration. Cairo: Dar Al-Nahtha Al-Arabia.

Sami, F. M. (2010) International Commercial Arbitration. Amman: Dar Al-Thaqafa Press.

Shafeeq, M. (1997). International Commercial Arbitration: A Study of International Commercial Law. Cairo: Dar Al-Nahtha Al-Arabia.

Shata, A. M. (2009). Explanation of Arbitration Law: A Comparative Study. Cairo: Dar Al-Nahtha Al-Arabia.

\section{Copyrights}

Copyright for this article is retained by the author(s), with first publication rights granted to the journal.

This is an open-access article distributed under the terms and conditions of the Creative Commons Attribution license (http://creativecommons.org/licenses/by/4.0/). 